УДК 821.161.2.02 «19»: [7.038.5: 141.82]

DOI https://doi.org/10.26661/2414-9594-2021-1-37

\title{
ТРЕВЕЛОГ ТОТАЛІТАРНОЇ ЕПОХИ: «ЛЮДИ МОРЯ» ІВАНА КОВТУНА
}

\author{
Юферева О. В. \\ доктор філологічних наук, дочент, \\ професор кафедри світової літератури та теорії літератури \\ Національний педагогічний університет імені М. П. Драгоманова \\ вул. Пирогова, 9, Київ, Україна \\ orcid.org/0000-0003-4700-8002 \\ elena.yufereva@gmail.com
}

\begin{abstract}
Ключові слова: література подорожі, сочреалізм, Розстріляне відродження, орієнталізм, наратив.
\end{abstract}

Стаття присвячується тревелогу «Люди моря» Івана Ковтуна, представника «Розстріляного відродження». Це остання публікація малодослідженого автора. Твір на поверхні виглядає маніфестом ключових радянських ідеологем. Але його комплексний аналіз сприяє унаочненню неочікуваних сюжетів і жанрових рішень на тлі подорожньої літератури радянського періоду. Завданнями розвідки є характеристика жанрових ознак твору I. Ковтуна «Люди моря», виявлення специфіки образу Сходу, а також засобів репрезентації «свого» простору. Подорож I. Ковтуна, з одного боку, відповідає критеріям літературної подорожі радянського періоду, а з іншого - виходить за їі межі, наприклад, долученням архаїчної моделі антипаломництва, фіксацією процесу пересування маршрутом, що притаманно традиції морської подорожі.

Сюжетна структура базується на портретному репортажі: книга розділена на п’ять частин, у центрі яких постає герой із команди пароплава «Курськ». Морська тема у творі представляє кілька важливих семантичних вимірів, які реалізуються через топос корабля, усталену метафору європейської літератури. Дидактичний режим втягує в коло радянських ідеологем ініціальний сюжет, характерний для літератури подорожі. «Курськ» можна вважати колективним соціальним портретом Радянського Союзу. Парадокс конструювання образу Сходу полягає в тому, що, незважаючи на програмне антиімперське ідеологічне спрямування, оповідь спирається на колоніальні метафори й опозиції. Аналіз твору доводить, що східні конструкти відсталості, зневаги та неповноцінності, визначені Е. Саїдом, перетворюються в тексті на знаряддя протиставлення радянської системи західній.

Автор статті робить висновок, що для подорожі I. Ковтуна «Люди моря» характерна еклектичність. Ідеологічна картографія стикається 3 естетичним баченням простору, дистанція - 3 емоційним сприйняттям. Східна формула, помножена на класовий підхід, трансформується: західні знаки зменшуються та знецінюються, а східна «відсталість» перекодується у класову пригнобленість. 


\title{
TRAVELOGUE OF THE TOTALITARIAN ERA: "PEOPLE OF THE SEA" BY IVAN KOVTUN
}

\author{
Yufereva O. V. \\ Doctor of Philological Sciences, Associate Professor, \\ Professor at the Department of Theory and World Literature \\ National Pedagogical Dragomanov University \\ Pyrogova str., 9, Kyiv, Ukraine \\ orcid.org/0000-0003-4700-8002 \\ elena.yufereva@gmail.com
}

Key words: travel writing, socialist realism, Executed Renaissance, orientalism, narrative.
The article is dedicated to the travelogue "People of the Sea" by Ivan Kovtun, a representative of Executed Renaissance. This is the last publication by a littlestudied author. The work on the surface looks like a manifesto of key Soviet ideologues. The author of this article intends to lay out unexpected plots and genre decisions of the travelogue on the background of travel literature of the Soviet period. The article is aimed to characterize the genre features of I. Kovtun's work "People of the Sea", to identify the specifics of the image of the East, as well as the means of representation of "their" space. I. Kovtun's travelogue in terms of content and genre, on the one hand, meets the criteria of literary travel of the Soviet period, and on the other hand, goes beyond it, for example, adding an archaic model of anti-pilgrimage, fixing the process of travel, which is inherent in the tradition of sea travel. The processes of genre and thematic transformation of travel in the 1930's can be seen in the work of the writer, comparing the early travelogue "Winged Raid", published in 1929, with the later - "People of the Sea". The "People of the Sea" is characterized by greater specificity, careful exploration of unfamiliar places and a completely different rhetoric, focused on the concepts of "industrialization" and "imperialism".

The plot structure is based on a portrait report: the book is divided into 5 parts, in the center of which the hero from the team of the steamer "Kursk" appears. The marine theme in the work represents several important semantic dimensions, which are realized through the topos of the ship, an established metaphor of European literature. The didactic mode draws into the circle of Soviet ideologemes the initial plot typical of travel literature, for example, the history of the proletarian upbringing of a Komsomol member. "Kursk" can be considered a collective social portrait of the Soviet Union.

The narrator's anthropological vision is rather limited. There is no "other" person in the work. The paradox is that despite anti-colonial criticism of Western policies, the narrative of the East in "People of the Sea" is based on the same colonial metaphors and oppositions. Oriental constructs of backwardness, neglect, and inferiority determined by E. Said turn into instruments of opposition of the Soviet system to the Western one.

The author of the paper concludes that I. Kovtun's travelogue "People of the Sea" is characterized by eclecticism. Ideological cartography is confronted with the aesthetic vision of space, distancing - with the emotional perception. The Oriental formula, multiplied by the class approach, is transformed: Western signs are reduced and devalued, and Eastern "backwardness" is recoded into class oppression.
Постановка проблеми. Проблема особливостей формування, розвитку та наслідків українського соцреалізму поступово набуває нових тлумачень. Але попри низку грунтовних праць (див., напр.: Т. Гундорова [2], Т. Свербилова [9], У. Федорів [11], В. Харкун [14], Ф. Штейнбук [18]), залишається чимало нерозкритих питань, непомічених явищ. Наприклад, творчість харківського письменника Івана Ковтуна (1906-1937 pр.), представника Розстріляного відродження, яка досліджена в літературознавстві фрагментарно. Увагу привертали переважно гумористичні твори, які 
видавалися під псевдонімом Юрій Вухналь. Водночас його романи, повісті, тревелоги досі прискіпливо не розглядалися. Трапляються неточності в систематизації бібліографії, так, в одній із розвідок зазначається, що остання публікація І. Ковтуна побачила світ у 1931 р. [16], але насправді в 1935 р., за рік до арешту. Це була книга «Люди моря» - результат подорожі, здійсненої в 1930 р. Хоча, справді, після 1931 р. у творчому житті письменника настає павза, яка, на думку Ю. Чуба, зумовлюється переживанням трагічних подій голоду, репресій $[15$, с. 24].

Твір «Люди моря» виглядає маніфестом ключових радянських ідеологем. Але його комплексний аналіз сприяє унаочненню неочікуваних сюжетів і жанрових рішень на тлі тодішньої подорожньої літератури. Сказати, що в тексті автор висловлює незгоду $з$ політичним курсом, звісно, не можна, як і заперечити ідеалізацію й утопічність «свого» простору. Проте є підстави стверджувати, що уникання знакових для сталінських часів міфологем, обов'язкових для соцреалістичної літератури, зосередження на «периферії», а не «центрі» (як у географічному (відсутність прив'язки до Москви - сакрального місця влади), так і в ідеологічному (не використання мілітаризованої риторики) смислах), є істотним відхиленням від літературного порядку денного. Утім, твір належить часу, складному, трагічному, загрозливому. Ця подорож відбиває глибинні процеси, які відбуваються в літературі й суспільстві сталінської епохи. Її вивчення сприяє розумінню, як формувалися техніки викривлення, в основі яких задіяний резерв жанрової традиції, як перекодовувалися сталі мотиви й образи. Отже, представлена стаття присвячується останній роботі Івана Ковтуна подорожнім нарисам «Люди моря».

Метою розвідки $є$ характеристика жанрових ознак твору I. Ковтуна «Люди моря», виявлення специфіки образу Сходу, а також засобів репрезентації «свого» простору.

Виклад основного матеріалу. Загальним місцем багатьох сучасних досліджень радянського тревелогу $\epsilon$ те, що він реактуалізує жанрову пам'ять подорожі під впливом політичних змін та вимог. На шляху до затвердження тоталітарного тревелогу інтенсивно вимиваються ознаки, які сприяли гнучкості подорожньої літератури, особливо в аспекті авторепрезентації. Звернемо увагу на завершення подорожі «Люди моря» - важливий етап, що виражає особистісні трансформації після зустрічі 3 «іншим», які намагається осмислити подорожній. У нашому творі автор різко уриває оповідь про малайзійське місто на вкрай негативних спостереженнях і показує себе в потязі до Харкова у клопотах із папугами і дитинчам макаки - екзотичними сувенірами, які ніби стали єдиним результатом морського вояжу для подорожнього. Ця змістова та структурна прогалина є вагомою в контексті подальшого розвитку тревелогу. Фактично, тут стверджується екзистенційна вичерпаність подорожі, адже вона нічого не змінює, що віддзеркалює завмирання розвитку, зміну місця жанру в літературній системі епохи.

Певна особистісна «незачепленість», відсутність усвідомлення унікальності власного досвіду стає парадоксальною нормою подорожі. Унаслідок цього дистанція, позиція, без якої, напевно, унеможливлюється спостереження або пізнання нового, перевтілюється у відстороненість, а спектр явищ, які подорожній помічає та презентує, гранично редукується. Тоді виникає закономірне питання: якщо подорож не виконує навіть інформативної функції, то яка іï мета? Соцреалістичні тревелоги, передусім у 1930-ті рр., говорили про «радянську людину» або «радянське» в людині, яке треба розгледіти, де б не опинився оповідач. Саме тому подорожня література вбирає в себе виховний дискурс, залишаючи обмаль місця для особистих вражень та міркувань. Проте як сконструювати наративну ілюзію причетності, без якої об'єктивація радянських цінностей на тлі «іншого», перетвореного на бутафорну сцену, не відбудеться?

Літературні подорожі 1920-х та 1930-х рр. підпорядковуються різним ідеологічним настановам: у добу сталінізму розвивається специфічний спосіб художнього уявлення простору, яке визначається «відмовою від географічного виміру» $[13$, c. 180$]$. С. Франк зазначає, що «радянсько-сталінське розуміння подорожі ідентифікується як новий тип іiі імперського розуміння» [13, с. 211]. Отже, дослідниця вважає, що в подальших дослідженнях радянські тревелоги 1930-х рр. варто розглядати в межах традиції імперської практики подорожей [13, с. 211]. Українські подорожі цього часу (насамперед ідеться про суто радянській тревелог, хоча за більш широкого підходу доцільно включати і галицький контекст (див., наприклад, одну з останніх монографій, присвячених цій проблематиці: [10])), демонструють більше розмаїття 3 концептуального погляду, що, як показується у студіях С. Кочерги [5], О. Омельчук [6], Т. Шестопалової [17], простежується в дотриманні тих традицій літератури мандрів, згідно з якими деталі, процес подорожування не втрачають чинності. Такі поєднання руйнують сталі жанрові моделі тревелогу сталінського періоду, які базуються на двох різновидах: паломницького ходіння й офіційного подорожнього звіту [1]. Поняття тоталітарного тревелогу як типу, що підпорядковує реальні враження ідеологічним уявленням [7, с. 68] та зближується з антипутівником, розвивається в роботі $Є$. Пономарьова. Але в зазначеній 
роботі розглядаються європейські подорожі російських письменників. Зрозуміло, географічне спрямування мандрівки та національна ідентичність автора-подорожнього зумовлюють жанрові та семантичні ознаки тревелогу, а отже, проблема визначення i динаміки тревелогу окресленого періоду потребує конкретизації й уточнень.

Процеси жанрової і тематичної видозміни подорожі 1930-х рр. можна помітити й у творчості I. Ковтуна, якщо порівняти ранній тревелог «Крилатий рейд», виданий у 1929 р., $з$ пізнішим «Люди моря». Таке порівняння дає уявлення і про творчу еволюцію письменника. У другому тревелозі повніше розкривається майстерність I. Ковтуна-прозаїка. Якщо в ранній мандрівці гумористичний живий діалог стає маркером авторського стилю та національної літературної традиції, то в останньому - до дотепних діалогів додаються художньо виразні живописні й портретні замальовки, а також примхлива жанрова організація.

«Крилатий рейд» присвячується радянському простору: автор із робітничою делегацією відвідує Сочі, Тифліс, Баку, - канонічний маршрут соцреалістичного тревелогу кінця 1920-х рр. У «Людях моря» зображується простір закордонних країн: Туреччини, Сгипту, Сінгапуру, Італії. Проте відмінності подорожей зумовлюються не тільки різним географічним спрямуванням, а й ідеологічною переорієнтацією, поетикальними особливостями. «Крилатий рейд» уславлює досягнення революції, становить ритуалізований тревелог святкування народження нової єдності: утопічна картина світу, яка підміняє справжній соціокультурний, природний ландшафт, позбавлена детальних описів, індивідуальних спостережень. Натомість подорожі «Люди моря» притаманна більша конкретика, уважне роздивляння незнайомих місць і абсолютно інша риторика, зосереджена на концептах «індустріалізація», «імперіалізм».

Попри спроби відбити неоднорідність іншого світу, насамперед його соціальної структури, зіткнення в ньому різних полюсів, пізній тревелог І. Ковтуна більшою мірою говорить саме про «свій» світ, що відокремлюється як від відсталого Сходу, так і від імперіалістичного Заходу. Таке відмежування унаочнює трансформації радянської літератури подорожі, унаслідок яких формується тоталітарний тревелог із репортажною динамікою, пропагандизмом, екскурсами в історію колонізаційної політики, критикою удаваної «незалежності» східних країн, диктатури імперіалістичного капіталу.

Репортажність у «Людях моря» відчутно домінує. Сюжетно-композиційна структура твору спирається на портретний репортаж: книга поділяється на п'ять частин, у центрі яких постає герой iз команди пароплава «Курськ». Різка поляризація свій/чужий, визначальна для радянського тревелогу, також є типовою рисою. Крім того, пролетарський подорожній за кордоном не тільки переживає «зверхнє» відчуття переваги власного штибу життя, а й наближує чужі реалії до «своїх». «Інший», з яким стикається мандрівник, на думку оповідача, ставиться до радянської людини або 3 повагою, або з обережністю. Так, коли подорожній наближається до берегів Туреччини, то бачить, як привітно салютують капелюхами із тротуарів, адже «радянський флаг тут у повазі» [4, с. 8]. Або репліка єгипетського шлюпника, яка засвідчує пролетарську солідарність: «Русія - гут, Арапка гут, Інгліш офіцер не гут» [4, с. 30].

Тревелог I. Ковтуна не є одновимірним, що зумовлюється впливом традиції морських подорожей. Морська тема у творі репрезентує кілька важливих змістових вимірів, які реалізуються через топос корабля, усталеної метафори європейської літератури. Найбільш вагомим видається ідентифікаційний вимір: «Курськ» - це «радреспубліка в мініатюрі» $[4$, с. 30], тобто символічний дім 3 ідеальним устроєм, який розкривається через ідеальних представників: на кораблі зібрано типажі радянської людини 3 найкращими якостями: свідомі моряки, досвідчений і дружній капітан, професійно бездоганний стерновий, відповідальний лікар, енергійний i завзятий матрос. Наратор постійно підкреслює чистоту й охайність членів команди, що є метонімією упорядкованості Радянського Союзу: щоб зустріти чужоземний берег, виголена команда в чистих комірцях виходить на палубу [4, с. 7], помічник капітана чекає санітарного лікаря в новенькому кашкеті [4, с. 8], а старий кочегар перш ніж зійти на берег неквапно прямує до ванни. На березі Сінгапуру моряки 3'являються «чисто виголені, охайно одягнені, в блискучих, вигладжених комірцях» [4, с. 36]. Секретар турбується, щоб вони випадково не забруднилися мастилом: «Хай побачать, що моряки радянські во-оо!» [4, с. 37]. Чистота радянського моряка семіотична ознака, яка відмежовує його і від аморального західного світу, і від брудного східного світу. У цьому аспекті проглядається і давня традиція, згідно $з$ якою «інший» простір є «нечистим». Прикметно, що і представники такого простору наділяються «нечистими», «нелюдськими» ознаками. Наприклад, на обличчях англійців «мертвів самовпевнений вираз непорушної байдужості» [4, с. 22], малайці нагадують «худих гострокрилих птахів» [4, с. 42]. Антипаломницькі риси, про які пише Б. Успенський у відомій роботі [8], помічаються також у структурі першого нарису, що буде зазначено нижче.

Цікаво, що специфічний радянський дидактизм, який у тревелогах поширюється передусім на чужий простір (і такий ракурс у творі представ- 
лений послідовно, зокрема, у порівнянні образу життя «інших» моряків і «наших»: поки чужоземні моряки цікавляться ресторанами і к'янті, радянські їдуть на екскурсію до Помпеї [4, с. 53], водночас поширюється і на «свій», що для закордонних поїздок $є$ досить нетиповим. У межах корабля проводити виховальну роботу доцільно, екстраполюючи етичні настанови на всю спільноту радянських громадян, тож нариси ілюструють каталог моральних приписів щодо наполегливої праці та навчання, правильного способу дозвілля та навіть зовнішнього вигляду. Моряк, який виходить за межі корабля, має бути обачним, мати пристойний вигляд, але не більше того, адже жодних загроз він не відчуває.

Дидактичний модус втягує в коло радянських ідеологем типовий для літератури мандрів ініціальний сюжет. Наприклад, історія пролетарського виховання комсомольця, головного персонажа першої частини книги: фізичні та духовні випробовування в корабельній буденності змінюють Чижика на Миколу Васильовича, достойну професії молоду людину.

Отже, «Курськ» можна вважати збірним соціальним портретом Радянського Союзу. Увагу привертає модель утопійного суспільства, створена уявою I. Ковтуна на кораблі. Х. Гюнтер, дослідник соцреалізму, зауважує, що в 1932-1935 рр. відбувся перехід від поняття «пролетаріат» до поняття «соціалістичний народ». Відтепер суспільство починає описуватися як піраміда, в основі якої - народ, а нагорі - вождь, отже, «нова модель суспільства будується на відмові від егалітарних мрій революційної епохи» [4, с. 45]. Прикметно, що I. Ковтун оминає тему вождів як у ранньому тревелозі «Крилатий рейд», так і в «Людях моря». Егалітарність, утілена у професійних і людських взаєминах моряків, для автора безперечний ідеал, який він постійно підкреслює. Наприклад, образ капітана, який дружньо ставиться до нижчої ланки корабельної ієрархії - кочегарів. Об'єктивацією ідеї того, що радянський спосіб суспільної організації є прикладом прогресивності і людяності, виступає приписана наратором свідкам-чужоземцям висока оцінка певної події: «Чужоземні гості вражено спостерігали незвичайну для них картину: за столами, вкритими білосніжними скатерками і обтяженими вечерею, запросто сиділи капітани й помічники поруч матросів, старші механіки - поруч кочегарів» [4, с. 72].

Образ корабля намічає медіаційний вимір - третій простір, або зону контакту, у якій налагоджується діалог і культурний обмін. Безпосередня зустріч із місцевими показується тільки тут, але зламати радянську культурну авторитарність, дистанцію не вдається. На кораблі з'являються як представники імперської влади, англійські поліцей- ські, так і класові «свої», пролетарії, як, наприклад, шлюпник Мустафа, якого подорожній пригощає радянськими цигарками та просить принести місцевих газет; або арабські солдати, з якими відбувається мовчазний діалог із пропозицією закурити. Англійським поліцейським символічних дарунків не пропонують. Проте й вони, коли потрапляють у цей простір, стають ближчими до команди i, ніби мимоволі, вступають у небажаний для них діалог, торкаються заборонених тем, натякають на несправедливість імперської влади, як-от епізод із п'яним «офіцериком» у Суезі [4, с. 29-30]. Другорядні постаті виконують чітку функцію: їхне невдоволення, показ вимушеної або недоречної поведінки окреслюються декількома штрихами, але цього досить, щоб підштовхнути читача до висновків у «правильному» руслі.

Традиції морської подорожі суттєво впливають і на поетикальний рівень тревелогу: в оповідь включається пейзажність, особливо виразна в першій частині, «Далекосхідному рейсі», де представлено не спогади членів команди, як у подальших нарисах, а безпосередньо авторські враження від побаченого. Образні пейзажі берегів, міст, океану характеризуються деталізацією, насиченими фарбами, гнучкістю ліній. Панорами, що відкриваються навколо Суецу або Неаполя, даються стислими мазками 3 яскравими кольоровими акцентами: «Аж до Везувія прослався Неаполь жовтогарячими, білими, синіми смугами, підступаючи до ясних забарвлених зеленню вілл Соренто. Густо-голуба затока покраплена золотом пекучого сонця. I сніжність вітрил овально вгиналась у білий берег. У бік, прозорій золотистій далині, запорошеній фіолетовим туманом, окреслювався Капрі» [4, с. 52]. Живописністю, динамікою позначені саме далекі плани, як-от вид Стамбула: «Треба признатись, своєрідна панорама Стамбула вражає і приваблює. В іiї обрисах незвичайно поєднані найрізноманітніші лінії: ось овальна м'яка лінія, що обгортає опуклі мечеті, враз рветься й ламано і стрімко починає викреслювати обрис мінарету, потім знову падає і спокійно лежить звичайною горизонтальною на плоских східних дахах» [4, с. 8]. Натомість в урбаністичних картинах інтермедіальна оптика зникає, а на iii місце приходить зовсім інший «зір». В описах міського побуту та краєвидів простежується дистанціювання. Природа передається здалека, згори, а побут - уривчастим нанизуванням прикмет 3 оцінковими коментарями: «Їх (туристів - О. Ю.) захоплює: вогкість темних квартир, замурзані рахітичні діти, лахміття старців, голодний погляд вуличного музиканта-жебрака, антисанітарні крамнички й кіоски з гнилими фруктами та продуктами, засидженими мухами. У путівниках $€$ розділи, де вихваляють і жахливі райони Неаполя 
$<\ldots>$ Неприхований глум» $[4$, с. 53$]$. Міста в I. Ковтуна одноманітно непривабливі та брудні, у якій би географічній точці вони не були, головне, що за межами Радянського Союзу. Тобто показ соціального буття спирається суто на ідеологічну вісь.

До суто пролетарського бачення долучається так званий «туристичний» погляд, який видає зацікавленого мандрівника, незважаючи на те, що це вже не перша його зустріч зі Сходом, принаймні з Туреччиною, що автор зазначає в тексті [4, с. 6]. Здивування і захоплення - найрідкісніші емоції радянського подорожнього за кордоном. Але тут оповідач часто вражений: Суецьким каналом, панорамою або морськими пригодами. Впадає в око звичайний, якщо не тривіальний, для літератури подорожі, проте зовсім не очікуваний у контексті епохи прогулянковий дискурс, трансформації якого в межах радянського тревелогу теж помітні. 3 одного боку, прогулянка східними містами або Неаполем визначається безтурботністю, але з іншого - позбавляється меланхолійності, рефлексивності. Основним емоційним модусом i враженням стає розчарування, а ієрархічне конструювання чужого простору фактично перекреслює можливість усвідомлення або відчуття іншої культури. Уривчастість оповідної конструкції, яка значно посилює негативізм сприйняття, свідчить i про те, що намірів подолати відчуженість не було. Уже під час першої прогулянки в Туреччині унаочнюється невідповідність побаченого очікуванням, тобто «убогість» (одне з найбільш уживаних слів для опису східного побуту) та бруд замість «усього незвичайного» [4, с. 10]. Зіткнення протилежних позицій - уявної та критичної, проте не аналітичної, - обриваються і повертають до вихідного, у ціннісному й географічному розумінні, виміру: «Батьківська Одеса набувала поваги цілком вчасно й заслужено» $[4$, с. 10$]$.

Екскурсія до Помпеї - єдиного культурноісторичного артефакту, який описується в тексті, увиразнює ще один спосіб наративізації іншого простору - злиття історичного минулого й теперішності: в очах подорожнього рабовласницька імперія нікуди не зникла. Проходячи крізь жанрові й ідеологічні фільтри, минуле міста позбавляється катастрофічності та трагізму. Подорожній не відчуває ані смутку, ані співчуття, що відрізняє його рецепцію Помпеї від традиційного образу цього міста в літературі та культурі. Тут також трапляється ситуація, яка демонструє, що перед нами наратив колективного самоствердження. Як уже зазначалося, подорожній надає великого значення тому, яким радянський «корабель» постає в очах «інших». У Неаполі театралізація такої ситуації стає очевидною: моряки перетворюються на своєрідний музейний експонат, на який збігається подивитися натовп, що для оповідача є цілком належною подією.
Як уже зазначалося, антропологічна візія наратора є досить обмеженою. Фактично, у творі «інша» людина відсутня. Зображуються в основному типи робітника (вантажник, шлюпник, рикша) в моменти важкої праці. У відтворенні поведінки місцевих впадає в око схематичність вони або радіють, або ніяковіють у присутності радянської команди, опускають очі, соромляться. I майже повсюдно замість них говорить оповідач. Це явище дуже нагадує те, що Е. Саїд називає орієнтальною мовчанкою [8] - ознаку орієнтального дискурсу, що зумовлюється дистанцією, яку тримає мандрівник-оповідач до конкретної людини Сходу та яка дозволяє йому через однозначно вище етичне становище описувати іiі згідно із власними уявленнями.

Парадокс полягає в тому, що попри антиколонільну критику політики західних країн, наратив Сходу в «Людях моря» спирається на ті самі колоніальні метафори й опозиції. Визначені Е. Саїдом орієнтальні конструкти відставання, занедбаності, неповноцінності перетворюються на інструменти протиставлення радянського устрою - західному, адже східний спосіб життя розглядається як у площині європейської колонізації, так і в радянській перспективі. Традиційний «імперський» погляд на Схід доповнюється класовим, а отже, бруд, сморід є не тільки знаками східного способу життя, а й маркерами поневолення, безправності. Відповідно знаки «європейськості» у східному просторі, упізнання яких у західного подорожнього обов'язково б викликало схвальну оцінку, тут такої позбавляються, погляд радянського мандрівника на них не затримується. Тому зрозуміло, чому у сприйнятті Неаполя орієнтальна оптика не змінюється.

Отже, «архаїчний» константинопольський порт занепадає, арабські квартали Єгипту - брудні, гнилі, нагадують «вогкі, зчорнілі домовини» $[4$, c. 17], селища на африканському березі виглядають як «брудна руїна» [4, с. 24], роботи на Суецькому каналі - провінціальні, кустарні $[4$, с. 26]. Принцип контрастного зображення європейської та місцевої частин міст, дистанційований погляд, протокольний, позбавлений експресії та живописності стиль мають підкреслити «об'єктивність» погляду. Автор вдається до поширених аспектів орієнтального письма, говорячи про організацію побуту містян східних країн. Східні традиції вуличної іжі в негативних конотаціях $є$ постійним мотивом у європейських тревелогах. Показ гастрономічних звичаїв в І. Ковтуна вирізняється не стільки відразою до побаченого, скільки тим, що саме цей епізод виступає завершальним етапом далекосхідної подорожі. Використані образи і метафори викликають асоціації з потойбічним світом: густий чад, суміш пари і смороду, димні 
вогнища і чудернацькі тіні, чадіння і шкварчання бляшаних жаровень [4, с. 42]. «Жодного слова, жодного звуку - лише зловісне шкварчання сковорід. Не знаю чому, але мені стало моторошно» [4, с. 43]. Якщо, на думку Б. Успенського, антипаломництво уподібнюється ходінню до пекла через подолання водного простору [4, с. 258], то в наративі «Людей моря» проглядається чітка реалізація саме цієї архаїчної моделі.

Висновки. Тревелог «Люди моря» I. Ковтуна характеризується еклектичністю та двоїстістю на стилістичному і змістовому рівнях. Ідеологічна картографія стикається з естетичним баченням простору, дистанціювання - 3 емоційністю сприйняття. Орієнтальна формула, помножена на класовий підхід, трансформується: знаки західної культури, сприйняті як імперські, згортаються та знецінюються, а східні - репрезентовані в дусі колоніального дискурсу - маскуються ідеєю класової пригнобленості.
Але складно не помітити, що в конструюванні образу Сходу задіяні риторичні фігури настільки «стерті», що сумніватися в літературному опосередкуванні вражень подорожнього не доводиться. Впадає в око ще одна закономірність, яка теж має тривалу літературну традицію - відмінність у сприйнятті природного й соціального середовища, яка сягає сентиментальної подорожі. Як тільки панорамне споглядання географічних особливостей регіону завершується, як тільки подорожній ступає на землю і вирушає в місто, вмикається жанрова пам'ять, виносяться на поверхню архаїчні складники, а компілятивна форма їхньої організації свідчить про скостеніння жанру подорожі. Нарешті, передача «соціальних» умов у межах «свого» простору, корабля, та поза ним підпорядковується спільним принципам: нашаруванню готових форм, театралізації, які приглушують голос оповідача, демонструють неможливість говорити відверто, а головне - особисто.

\section{ЛIТЕРАТУРА}

1. Балина М. Литература путешествий. Сочреалистический канон. Санкт-Петербург : Академический проект, 2000. С. 896-909.

2. Гундорова Т. Замість передмови, або Соцреалізм між модерном і авангардом. Украӥнська драма 30-х рр. як модель масової культури та історія драматургї у постатях / Т. Свербілова, Л. Скорина. Черкаси : Маклаут, 2007. С. 4-17.

3. Гюнтер Х. Соцреализм и утопическое мышление. Соиреалистический канон. Санкт-Петербург : Академический проект, 2000. С. 41-48.

4. Ковтун І. Люди моря. Харків ; Одеса : Дитвидав, 1935. 87 с.

5. Кочерга С. Епістолярний травелог Валер'яна Поліщука. Наукові записки Національного університету «Острозька академія». Серія «Філологія». 2018. Вип. 4 (72). С. 183-187.

6. Омельчук О. Український претекст Жака Дерріда, або літературне пілігримство 1920-х. Слово $і$ час. 2009. № 7. С. 3-10.

7. Пономарев Е. Типология советского путешествия: «Путешествие на Запад» в русской литературе 1920-1930-х гг. : дис. ... докт. филол. наук. Санкт-Петербург, 2014. 577 с.

8. Саїд В. Орієнталізм. Київ : Вид-во Соломії Павличко «Основи», 2001. URL: http://edward-said.narod. $\mathrm{ru} /$ orientalism.htm (дата звернення: 20.03.2021).

9. Свербілова Т. Проект національної самоідентифікації вітчизняного соцреалізму та драма 30-х рр. ХХ ст. Слово і час. 2008. № 4. С. 21-29.

10. Стратегії мемуарної та мандрівної літератур західноукраїнських письменників другої половини XIX - першої половини XX ст. : колективна монографія / відп. ред. Т. Пастух. Національна академія наук України, Інститут українознавства ім. І. Крип'якевича. Львів, 2020. 572 с.

11. Успенский Б. Дуалистический характер русской средневековой культуры (на материале «Хожения за три моря» Афанасия Никитина). Избранные труды / Б. Успенский. Москва : Гнозис, 1994. Т. 1 : Семиотика истории. Семиотика культуры. С. 254-297.

12. Федорів У. Соцреалістичний канон в українській літературі: механізми формування та трансформації : дис. ... канд. філол. наук. Львів, 2016. 227 с.

13. Франк С. Русские травелоги середины 1930-х гг. Беглые взгляды: новое прочтение русских травелогов первой трети XX в. Москва : Новое литературное обозрение, 2010. С. 180-212.

14. Харкун В. Соцреалістичний канон в українській літературі: генеза, розвиток, модифікації. Ніжин : ТОВ «Гідромакс», 2009. 508 с.

15. Чуб Д. Талановитий гуморист і сатирик Юрій Вухналь (1906 -1937-1977). Сучасність. 1978. Ч. 10 (214). С. 20-25.

16. Шептицька Т. Розстріляне відродження: архівно-кримінальна справа Юрія Вухналя. Науковий часопис Національного педагогічного університету імені М.П. Драгоманова. Серія 8 «Філологічні науки (мовознавство та літературознавство)». 2019. Вип. 12. С. 81-86. 
17. Шестопалова Т. «<..> не світ інший, а межі інші, і в цьому вся суть» (феноменологія одного епістолярного тревелогу Юрія Шевельова). Наукові праці. Філологія. Літературознавство. Миколаїв, 2017. Т. 301. № 289. С. 93-99.

18. Штейнбук Ф. Під «Знаком Саваофа», або «Там, де <..>» Ульяненко. Київ : Видавничий дім Дмитра Бураго, 2020. Ч. 1.396 с.

\section{REFERENCES}

1. Balina, M. (2000) Literatura puteshestvij. Socrealisticheskij kanon. SPb. : Akademicheskij proekt. 896-909.

2. Gundorova, T. (2007) Zamist' peredmovi, abo Socrealizm mizh modernom i avangardom. Ukrayins'ka drama 30-h rr. yak model' masovoyi kul'turi ta istoriya dramaturgyyi u postatyah In T. Sverbilova, L. Skorina (Ed.) Cherkasi : Maklaut. 4-17.

3. Gyunter, H. (2000) Socrealizm i utopicheskoe myshlenie. Socrealisticheskij kanon, SPb. : Akademicheskij proekt. 41-48.

4. Kovtun I. (1935) Lyudi morya. Harkiv; Odesa : Ditvidav.

5. Kocherga, S.O. (2018) Epistolyarnij travelog Valer'yana Polishchuka. Naukovi zapiski Nacional'nogo universitetu "Ostroz'ka akademiya": seriya "Filologiya". Ostrog : Vid-vo NaUOA. Vip. 4 (72), gruden'. 183-187.

6. Omel'chuk, O. (2009) Ukrayins'kij pretekst Zhaka Derrida, abo literaturne piligrimstvo 1920-h. Slovo $i$ chas. № 7. 3-10.

7. Ponomarev, E.R. (2014) Tipologiya sovetskogo puteshestviya: "Puteshestvie na Zapad" v russkoj literature 1920-1930-h godov, Dissertaciya ... doktora filologicheskih nauk, Sankt-Peterburg.

8. Sayid, V.E. (2001) Oriyentalizm. K. : Vid-vo Solomiyi Pavlichko “Osnovi”. URL: http://edward-said. narod.ru/orientalism.htm (data zvernennya: 20.03.2021)

9. Sverbilova, T. (2008) Proekt nacional'noyi samoidentifikaciyi vitchiznyanogo socrealizmu ta drama 30-h rokiv XX st. Slovo i Chas. № 4. 21-29.

10. Strategyyi memuarnoyi ta mandrivnoyi literatur zahidnoukrayins'kih pis'mennikiv drugoyi polovini XIX - pershoyi polovini XX stolittya. (2020) Kolektivna monografiya In T. Pastuh (Ed.). Nacional'na akademiya nauk Ukrayini, Institut ukrayinoznavstva im. I. Krip'yakevicha. L'viv

11. Uspenskij, B. A. (1994) Dualisticheskij harakter russkoj srednevekovoj kul'tury (na materiale "Hozheniya za tri morya" Afanasiya Nikitina). Izbrannye trudy. T. 1. Semiotika istorii. Semiotika kul 'tury. M. : "Gnozis". 254-297

12. Fedoriv, U.M. (2016) Socrealistichnij kanon v ukrayins'kij literaturi: mekhanizmi formuvannya ta transformaciyi. Disertaciya ... kandidata filologichnih nauk, L’viv

13. Frank, S. (2010) Russkie travelogi seredini 1930-h. Beglye vzglyady: novoe prochtenie russkih travelogov pervoj treti $X X$ v., M. : Novoe literaturnoe obozrenie. 180-212.

14. Harkun, V. (2009) Socrealistichnij kanon v ukrayins'kij literaturi: geneza, rozvitok, modifikaciyi. Nizhin : TOV "Gidromaks".

15. Chub, D. (1978) Talanovitij gumorist i satirik Yurij Vuhnal' (1906-1937-1977). Suchasnist’. Ch. 10 (214). 20-25.

16. Sheptic'ka, T. (2019) Rozstrilyane vidrodzhennya: arhivno-kriminal'na sprava Yuriya Vuhnalya. Naukovij chasopis NPU im. M.P. Dragomanova. Seriya 8. Filologichni nauki (movoznavstvo ta literaturoznavstvo). Vip. 12. 81-86.

17. Shestopalova, T.P. (2017) "< ..> ne svit inshij, a mezhi inshi, i v c'omu vsya sut"” (fenomenologiya odnogo epistolyarnogo trevelogu Yuriya Shevel'ova). Naukovi praci. Filologiya. Literaturoznavstvo. Mikolayiv. Tom 301. № 289. 93-99.

18. Shtejnbuk, F. (2020) Pid “Znakom Savaofa”, abo "Tam, de <...” Ul’yanenko. Ch. 1. Kiyiv. Vidavnichij dim Dmitra Burago. 